\title{
TTR
}

Traduction, terminologie, re?daction

\section{Paul Ricoeur. On Translation. Translated by Eileen Brennan. With an Introduction by Richard Kearney. London and New York, Routledge, 2006, Pp. xx + 46 .}

\section{Corrado Federici}

Volume 19, numéro 1, 1er semestre 2006

Figures du traducteur/Figures du traduire I

Figures of Translators/Figures of Translation I

URI : https://id.erudit.org/iderudit/016668ar

DOI : https://doi.org/10.7202/016668ar

Aller au sommaire du numéro

Éditeur(s)

Association canadienne de traductologie

ISSN

0835-8443 (imprimé)

1708-2188 (numérique)

Découvrir la revue

Citer ce compte rendu

Federici, C. (2006). Compte rendu de [Paul Ricoeur. On Translation. Translated by Eileen Brennan. With an Introduction by Richard Kearney. London and New York, Routledge, 2006, Pp. xx + 46.] TTR, 19(1), 223-225.

https://doi.org/10.7202/016668ar

Tous droits réservés (C TTR: traduction, terminologie, rédaction Les auteurs, 2007
Ce document est protégé par la loi sur le droit d'auteur. L'utilisation des services d'Érudit (y compris la reproduction) est assujettie à sa politique d'utilisation que vous pouvez consulter en ligne.

https://apropos.erudit.org/fr/usagers/politique-dutilisation/ 
En conclusion, l'auteur pose la question suivante : « la théorie des biens symboliques interprétée en termes de traductologie suffit-elle pour rendre compte de l'essentiel de ce qui se passe en traduction? " (p. 169) Si elle permet de tenir compte de l'aspect socio-historique des traductions, Gouanvic affirme avoir parfois recours à ce qu'il nomme les «composantes techniques» des théories de Meschonnic et de Berman (signifiance, tendances déformantes), qu'il s'approprie pour les besoins de son approche. C'est ce qui lui fait dire que la théorie sociologique en traduction est " à la fois nécessaire et non suffisante " (p. 169). En somme, par le biais de la théorie sociologique en traduction, Gouanvic parvient à bien montrer les enjeux sociohistoriques du phénomène de traduction massive des romans américains dans la France de l'après-guerre, mais il n’hésite pas à emprunter des outils à d'autres courants traductologiques pour venir compléter son approche, principalement pour l'analyse textuelle. On ne peut que saluer cette ouverture de l'auteur qui parvient à marier des approches qui peuvent a priori sembler incompatibles, mais qui, combinées, lui permettent de mieux sonder l'univers riche et complexe de la traduction.

\section{Savoyane Henri-Lepage Université McGill}

\section{Paul Ricour. On Translation. Translated by Eileen Brennan. With an Introduction by Richard Kearney. London and New York, Routledge, 2006, Pp. xx +46 .}

Appearing in Routledge's Thinking in Action, "a major new series that takes philosophy to the public," this slim but dense volume contains three essays originally published in France under the title Sur la traduction (Paris, Bayard, 2004): "Translation as challenge and source of happiness," "The paradigm of translation," and "A 'passage': translating the untranslatable.” In his elegant introduction, Charles B. Seelig Chair of Philosophy at Boston College and author of more than 20 books, Richard Kearney offers a concise and informative overview of the intellectual itinerary of arguably one of the most prominent and prolific writers of the twentieth-century, positioning his hermeneutics, or inquiry into meaning and interpretation, within the context of the thought of Wilhelm Dilthey, Martin Heidegger, Hans-Georg Gadamer, and Edmund Husserl. He also situates his philosophy of translation within the context of the thought of Benedetto Croce, Walter Benjamin, 
and Jacques Derrida. What is significant for the discipline of Translation Studies is the fact that Kearney explains with great lucidity the implications of the interconnections between Ricœur's hermeneutics and translation theory and practice.

In "Translation as challenge and source of happiness" (original title, "Défi et bonheur de la traduction"), the text of an address given at the German Historical Institute in Paris in 1997, Ricœur reflects on Antoine Berman's The Test of the Foreign (L'épreuve de l'étranger, 1985) in conjunction with aspects of the theories of Sigmund Freud, in developing the complementary notions of translation as the "work of remembering" and as the "work of mourning." Ricœur uses these phrases, with their philosophical and psychological connotations, to refer to the process of translation in which "work is advanced with some salvaging and some acceptance of loss” (p. 3). What Ricœur does here is examine, from a hermeneutical perspective, the translator's dilemma of choosing between fidelity and betrayal, or equivalence and inadequacy, which is to say the impasse caused by the collision of the assertion of the untranslatability of the source text with the work of translation that occurs nonetheless. Ricœur provides a philosophical solution to this paradox articulating his concept of “'linguistic hospitality': where the pleasure of dwelling in the other's language is balanced by the pleasure of receiving the foreign word at home, in one's own welcoming house” (p. 10).

Ricœur continues to examine the translatable versus untranslatable "ruinous alternatives," as he calls them, (p. 13) in "The paradigm of translation," (original title, "Le paradigme de la traduction"), the inaugural lecture at the Faculty of Protestant Theology, Paris, 1998. His reflections revolve around the problem as formulated by Antoine Berman in The Test of the Foreign and by George Steiner in After Babel, although Ricœur's wide-ranging speculations bring him into contact as well with the ideas of Wilhelm von Humboldt, Benjamin Lee Whorf, E. Sapir, Walter Benjamin, Umberto Eco, Noam Chomsky, and Hannah Arendt. At the heart of these reflections is the question of whether or not a perfect, paradisiacal language subtends the plurality of languages. He states the alternatives in these terms: "either the diversity of languages gives expression to a radical heterogeneity-and in that case translation is theoretically impossible; one language is untransalatable a priori into another. Or else, taken as a fact, translation is explained by a common fund that renders the fact of translation possible; but then we must be able to find 
this fund, and this is the original language track" (p. 13). In this essay Ricœur returns to the "remembering" and "mourning" metaphors of translation introduced in the first essay, inviting the reader to accept his own metaphor of "linguistic hospitality," which he proposes as a model for other kinds of hospitality: "confessions, religions, are they not like languages that are foreign to one another, with their lexicon, their grammar, their rhetoric, their stylistics which we must learn in order to make our way into them?” (pp. 23-24).

“A 'passage': translating the untranslatable” (original title, "Un 'passage': traduire l'intraduisible") first appeared in Sur la traduction. It takes up once more the author's discussion on the relationship between the translatable and the untranslatable, between equivalence and equivalence without identity, and between internal and external translation. Moving from the theories of Ferdinand de Saussure and Émile Benveniste with respect to the basic units of meaningful language, Ricœur rejects the usefulness of literal translation saying: "Translators know it perfectly well: it is texts, not sentences, not words, that our texts try to translate. And texts in turn are part of the cultural groups through which different visions of the world are expressed” (p. 31). In making such observations, Ricœur provides a valuable philosophical grounding to a much-discussed concept in recent translation theory, that of the translator as cultural mediator. He argues, for instance, that, "absorbing vast interpretations of the spirit of a culture, the translator comes down again from the text, to the sentence and to the word" (p. 31).

As should be evident from the foregoing, this slim volume packs an enormous quantity of important reflection on the process of translation and its two fundamental approaches: the translation of words and phrases or the interpretation of meaningful wholes. In proposing what Kearney calls "the ethics of translation as an interlinguistic hospitality” (p. xx), Paul Ricœur offers invaluable insights into key notions in translation theory such as the Other, equivalence, fidelity, retranslation, and untranslatability. As a result, his hermeneutics as translation, or translation as hermeneutics, constitutes a significant frame within which the discourse on translation's methodologies can be further theorized.

Corrado Federici Brock University 